\title{
INFLUENCE OF DRIP IRRIGATION RATES AND SOIL IMPROVERS ON THE PERFORMANCE OF SOME SUGAR BEET VARIETIES IN NORTH SINAI
}

\author{
Ahmed S. Attaya* \\ Plant Prod. Dep., Fac. Environ. Agric. Sci., Arish Univ., North Sinai, Egypt
}

Received: 06/02/2017 ; Accepted: 01/03/2017

\begin{abstract}
The presented work aims to study the effect of drip irrigation rates and soil conditioners/ improvers on yield and quality of three sugar beet varieties during two winter successive seasons 2012/2013 and 2013/2014 under new land conditions of North Sinai Governorate, Egypt. Statistically split-split plot design was used. Irrigation rates had a significant effect on root length, root diameter, sucrose percentage, root and sugar yields in both growing seasons while it had a significant effect on purity percentage in $1^{\text {st }}$ season only. Irrigation rate of $3000 \mathrm{~m}^{3} /$ fad., over passed that of 2500 $\mathrm{m}^{3} /$ fad., which recorded the highest values of root diameter, sucrose percentage, purity percentage, root and sugar yields. On the other hand, Irrigation rate of $2500 \mathrm{~m}^{3} /$ fad., over passed that of 3000 $\mathrm{m}^{3} /$ fad., which recorded the longest root. Moreover, sugar beet varieties had a significant effect on root length, root diameter, sucrose percentage, root and sugar yields in both growing seasons while it had a significant effect on purity percentage in $1^{\text {st }}$ season only. Marathon variety gave the highest values of root length, root diameter, root and sugar yields. Farida variety gave the highest values of sucrose and purity percentages. Soil improvers had a statistical effect on root diameter, purity percentage, root and sugar yields in both growing seasons while it had a significant effect in $1^{\text {st }}$ season only on root length and sucrose percentage. Iquet compound was the best soil improver that attained the highest values of the studied traits in both seasons. The $2^{\text {nd }}$ order interaction of irrigation rate $\times$ variety $\times$ soil improver statistically affected on root diameter in $1^{\text {st }}$ season, sucrose and purity percentages in $2^{\text {nd }}$ season and root length, root and sugar yields in both seasons. Using $3000 \mathrm{~m}^{3} /$ fad., of irrigation rate in combination with Humic acid as soil conditioner for Marathon variety was the best combination that recorded the highest root and sugar yield values (30.58 and 5.99 ton/fad., respectively, as a mean of both seasons). However, using the same irrigation rate in combination with the same soil conditioner for Farida sugar beet variety attained the highest purity percentage value $(96.77 \%)$. The combination of $3000 \mathrm{~m}^{3} / \mathrm{fad}$., with Iquet for Marathon variety gave the highest root diameter value $(26.8 \mathrm{~cm})$ while the same combination with Farida variety recorded the highest sucrose percentage value $(20.06 \%)$. Thus, the combination of $2500 \mathrm{~m}^{3} /$ fad., with Iquet for Marathon variety attained the highest root length $(35.3 \mathrm{~cm})$.
\end{abstract}

Key words: Irrigation rate, soil improvers, sugar beet varieties

\section{INTRODUCTION}

Sugar beet (Beta vulgaris L.) is considered to be the second most important sugar crop, after sugar cane, due to its production annually of $45 \%$ of the global sugar supply. Sugar beet is an

\footnotetext{
${ }^{*}$ Corresponding author: Tel. : +201021289944

E-mail address: ahmd.attaya@gmail.com
}

economic crop in newly reclaimed areas and it produces more sugar under these conditions as compared with sugar cane. Division of Foreign Agriculture Service, United States Department of Agriculture (FAS-USDA 2016), reported that in 2015/16 season (Fig.1), Egypt produced 2.12 


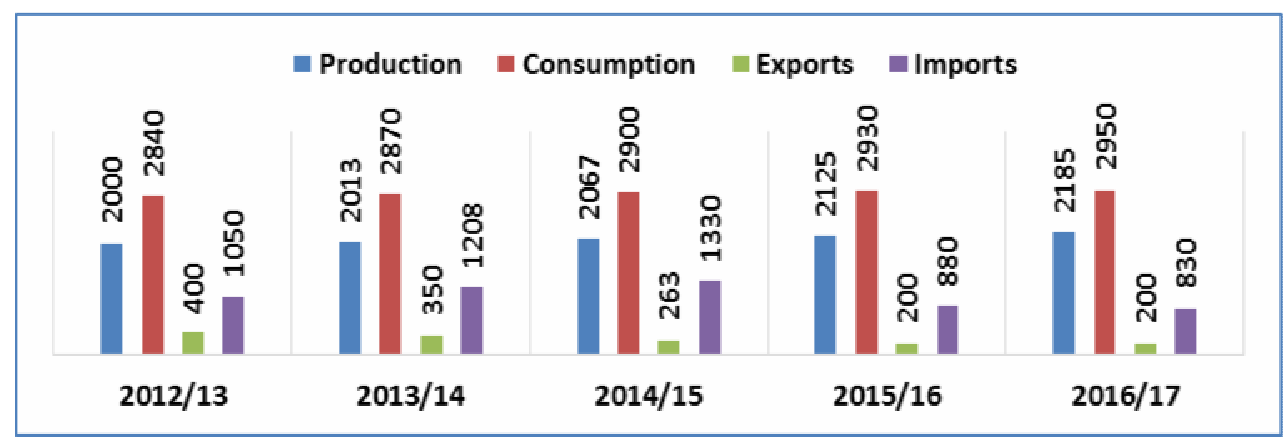

Fig. 1. Egypt's total production and consumption (1000 Metric tons)

Source: Foreign Agriculture Service, United States Department of Agriculture (FAS-USDA 2016)

million tons of sugar from 396,000 fad., of beet and 311,000 fad., of cane. Egypt consumes around 3 million tons (2.9, exactly) of sugar a year, using imports to fill the gap between production and consumption of sugar which reaches now nearly (765.000 tons). The increase in area harvested is due to the government's policy to encourage farmers to grow beets over cane to conserve water and also for its high sugar extraction that reaches 15-22 percent compared to only 14-16 percent for cane.

Sugar beet is grown in the Nile Delta region while sugar cane is grown in southern Egypt. Sugar beet is a new winter sugar crop and it has been a very successful crop in North Sinai, because it is tolerant to the shortage of irrigation water and the high salinity of the soil and water. Moreover, it is used for untraditional feed for large animals, sheep, and goats in North Sinai. Furthermore, there are some secondary industrial products from the residual leaf and root material. These residual and secondary products can supplement the income of farmers who produce sugar beet.

The performance of sugar beet varieties with respect to yield and the components of yield was studied by many authors. El-Hinnawy et al. (2003) found that sugar beet varieties differed significantly in sucrose content and purity percentage. El-Hennawy and El-Hawary (1995) and Bhullar et al. (2009) reported that sugar beet varieties differed in root and sugar yields (ton/ fad.) as well as in sucrose percentage. Al-Sayed (1997) found large variances among sugar beet varieties with respect to top, root, sugar yields (ton/fad.), and sucrose percentage. El-Hawary and Mokadem (1999) found that there was a magnitude variation among sugar beet varieties regarding all the studied characters in both seasons. Oscar poly variety gave the highest values of fresh root weight, relative root yield and yields of top, root and sugar than other two sugar beet varieties. Abou-Salama and El-Sayed (2000) showed that root and sugar yields varied between cultivars: the mean root yield was 16.50 ton/fad., for cv. Ras poly and 26.10 ton/fad., for cv. Gazella. Sugar yield was highest (3.09 ton/fad.) in cv. Oscar poly. Soomro et al. (2006); Siodmiak (2007) and Ijoyah et al. (2008) evaluated the yield performance of sugar beet varieties and they found that varieties were significantly differed. Safina and Fatah (2011) reported that sugar beet varieties differed significantly in purity percentage, sucrose percentage, extractable sugar percentage, root and sugar yields traits in both seasons except for sugar yield and purity (\%) in $1^{\text {st }}$ season only. Ahmad et al. (2012) evaluated four sugar beet hybrid varieties under Pakistan soil conditions and they found that SD-PAK09/07 variety attained the highest sugar yield $(9.35 \mathrm{ton} / \mathrm{ha})$ with highest sugar content $(12.60 \%)$ and root yield (74.2 ton/ha) followed by California and Magnolia varieties that gave sugar yield ( 7.08 and 6.99 ton/ha), respectively. The Mirabella variety produced a minimum sugar yield (4.44 ton/ha) and the lowest root yield among the tested varieties (40.33 ton/ha). Ahmad et al. (2012) also showed that there were no significant differences in root yield and size between the experimental varieties. El-Hawary 
et al. (2013) found that sugar beet varieties significantly differed in TSS (\%), sucrose (\%), and root and sugar yields/faddan in both seasons. The sugar beet variety Farida produced the highest values of TSS (\%), sucrose (\%), and root yield/faddan and sugar yield/faddan compared to other varieties in both seasons. Pacuta et al. (2013) found that Fred variety achieved the best production parameters from among four sugar beet varieties (Jambus, Tilman, Antek and Fred) and the highest sugar content was found in Tilman variety. LiangMin et al. (2014) evaluated three sugar beet varieties under Chinese soil conditions and they reported that the root yield of KWS7125 variety was 74.88-101.96 ton/ha, with $14.58-16.53 \%$ sugar content, while KWS0143 variety gave 85.8689.21 ton/ha root yield and 13.41-15.74\% sugar content and the KWS2049 variety gave 77.77 106.81 ton/ha root yield and 13.90-14.80\% sugar content. Al-Sayed and Attaya (2015) reported that sugar beet varieties were significantly differed in root length in the $1^{\text {st }}$ season, root diameter in the $2^{\text {nd }}$ season, root and sugar yields in both seasons. The highest values of root length and root diameter were resulted from Farida sugar beet variety. While, the highest values of juice purity percentage and sucrose percentage were resulted from Toro sugar beet variety. Also, Halawa variety attained the highest root and sugar yields.

Regarding the effect of irrigation rates on yield and its components, El-Hennawy and ElHawary (1995) found that increasing depletion level of soil moisture significantly decreased yields of top, root and sugar (ton/fad). On the other hand, sucrose (\%) significantly increased with increasing depletion level of soil moisture. Abd El-Wahab et al. (1996) reported that root and sugar yields (ton/fad.) were significantly increased as the level of irrigation increased, but sucrose $(\%)$ decreased with increasing levels of irrigation. Ramazan et al. (2011) found that increasing water deficits resulted in a relatively lower root and white sugar yields. El-Hawary et al. (2013) found that decreasing the amount of irrigation water from $3000 \mathrm{~m}^{3}$ to 2500 and 2000 $\mathrm{m}^{3}$ caused reductions in root and sugar yields per faddan. But, on the other hand, it increased the sucrose percentage in both seasons. AlSayed et al. (2014) noted that application irrigation rate of $2500 \mathrm{~m}^{3} /$ fad., recorded significantly the higher root length and purity percentage traits, meanwhile irrigation rate of $3000 \mathrm{~m}^{3} /$ fad., significantly raised root diameter and root yield traits.

Soil improvers/fertilizers importance for sugar beet production were reported by Blomquist and Berglund (2002), who showed that slaked lime (calcium hydroxide) improved the experimental soil and increased sugar yields. Negm et al. (2005) studied the response of sugar beet to sawdust compost (4 and 8 ton/fad.) and farmyard manure (12 tons/fad.) with combination of $\mathrm{N}$ sources, they reported that manuring increased the root yield of sugar beet significantly over the control, without differences between the three experimental manure treatments. Wallace and Carter (2007) studied the effect of compost on sugar beet yield. They found that the addition of organic matter, and nutrients from the application of compost, improved soil fertility and led to a $7 \%$ average increase in sugar beet yield. Zarishnyak and Sypko (2010) found that the application of press mud increased root yield to $40.2-45.8$ tons/ha compared to 26.2 tons/ha for the unfertilized control. Sugar yields were also increased to $6.9-8.0$ tons/ha compared to 4.6 tons/ha for the control. Ambihai and Gnanavelrajah (2013) found that the addition of charred biomass had the potential to increase the root yield by improving soil properties and reducing losses due to leaching. Al-Sayed and Osman (2015) studied three soil treatments (control, Aquita and potassium humate) on yield and its components of two sugar beet varieties (Farida and Marathon), they found that both of soil treatment compounds attained a positive and significant increase on the studied traits compared with control.

The objective of this investigation was to study the effect of different irrigation rates and soil conditioners on yield and quality of three sugar beet varieties under new land conditions of North Sinai Governorate, Egypt.

\section{MATERIALS AND METHODS}

Two field experiments were conducted in the Experimental Farm, Environmental Agricultural Sciences Faculty (FEAS), Suez Canal University, North Sinai Governorate, Egypt ( $31^{\circ} 08^{\prime} 04.3^{\prime \prime}$ N, 
$33^{\circ} 49^{\prime} 37.2^{\prime \prime E}$ ) during two winter successive seasons, 2012/2013 and 2013/2014, to study the effect of two rates of drip irrigation (2500 and $3000 \mathrm{~m}^{3} / \mathrm{fad}$.) and three soil improvers (Iquet, $(9 \% \mathrm{Zn}, 3.5 \% \mathrm{CaO}, 0.6 \mathrm{~S})$ powder which was added to the soil before sowing at the rate of 10 $\mathrm{kg} / \mathrm{fad}$., and Agrispon (liquid at the rate of 1 $\mathrm{cm} / 10 \mathrm{~m}^{2}$ ) and Humic acid $10 \% \mathrm{~K}_{2} \mathrm{O}$ (powder at the rate of 2 gram/litre) which were added after thinning\} on yield and its components of three sugar beet varieties: (Marathon, monogerm variety, as well as Farida, and Samba, multigerm varieties). The experiments were carried out in split-split plot design with three replications. The irrigation rates were randomly distributed in main plots, varieties in the sub-plots and soil conditioners were allocated at random in subsub plots. The plot area was $15 \mathrm{~m}^{2}(6$ rows $\times 0.5$ $\mathrm{m}$ width $\times 5 \mathrm{~m}$ length).

Seeds of sugar beet varieties were provided by the Sugar Crops Research Institute (SCRI) Agricultural Research Center (ARC) Giza, Egypt. Sowing date was on the first week of October in both seasons, Sugar beet seeds were sown into hills $20 \mathrm{~cm}$ apart. When the plants reached at four leaf stage, they were thinned to one plant/hill. Phosphorus, in form of calcium super phosphate $\left(15.5 \% \mathrm{P}_{2} \mathrm{O}_{5}\right)$, was added at a rate of $30 \mathrm{~kg} \mathrm{P}_{2} \mathrm{O}_{5} / \mathrm{fad}$., at sowing. Potassium sulfate $\left(48 \% \mathrm{~K}_{2} \mathrm{O}\right)$ was applied at a rate of $50 \mathrm{~kg}$ $\mathrm{K}_{2} \mathrm{O}$ /fad., with the first nitrogen application. Nitrogen fertilizer was applied as ammonium sulfate $(20 \% \mathrm{~N})$ at a rate of $120 \mathrm{~kg} / \mathrm{fad}$., in three equal doses: after thinning, one month later, and three weeks later. Other cultural practices were done as recommended. Soil samples were selected randomly from different sites of the experimental field, from a depth of $0-30 \mathrm{~cm}$ (from the soil surface) before sowing. Chemical analysis of the irrigation water are presented in Table 1 also, chemical and physical properties of the experimental soil are presented in Table 2.

\section{Data Recorded}

At maturity (190 days from sowing) four guarded rows for each treatment were harvested, topped and cleaned. A sample of ten roots was taken at random from each plot to determine the following parameters

1- Root diameter $(\mathrm{cm})$

2- Root Length (cm)
3- Sucrose percentage was determined by using Sacchrometer according to the methods of AOAC (1990).

4- Juice purity percentage was calculated according to the method describing by Carruthers and Old Field (1961).

Juice purity $(\%)=\{$ Sucrose $(\%) \times 100 /$ TSS $\}$

5- Root yield (ton/fad.) was determined by harvest the four guarded rows, topped and weighted.

6- Sugar yield (ton/fad.) was calculated according the following equation:

Theoretical sugar yield (ton/faddan $=$ Root yield $($ ton/fad.) $\times$ Sucrose $(\%)$

\section{Statistical Analysis}

Data collected were subjected to the statistical analysis according to the methods described by Steel et al. (1997). Statistical difference among the means was analyzed by Duncan's multiple range test (DMRT) Duncan (1995) using the SAS (SAS Institute, 2000) and the results were expressed as the mean $\pm \mathrm{SE}$. Data were also subjected to analysis of variance (ANOVA).

\section{RESULTS AND DISCUSSION}

The following discussion will include the effect of main factors on the studied characteristics, and because root yield is a final product for the growers and sugar is the final product for sugar factory, the interaction study will mean by the interaction between the studied factors on root and sugar yields only.

\section{Root Length}

Results given in Tables 3 and 4 show that root length of sugar beet varieties significantly affected by the examined irrigation rates in both growing seasons. Irrigation rate had a statistically significant effect for each level of variety $\times$ soil improver on the mean root length, $\mathrm{p}<0.005$ in $1^{\text {st }}$ season and $\mathrm{p}<0.001$ in $2^{\text {nd }}$ season. Irrigation rate of $2500 \mathrm{~m}^{3} / \mathrm{fad}$., over passed that of $3000 \mathrm{~m}^{3} / \mathrm{fad}$., which recorded the longest root $\left(31.3 \mathrm{~cm}\right.$ in $1^{\text {st }}$ season and $32.6 \mathrm{~cm}$ in $2^{\text {nd }}$ one). This finding is in harmony with that found by Al-Sayed et al. (2014) who noted that root length significantly increased with lower rate of irrigation water $2500 \mathrm{~m}^{3}$. This finding may due to that less amount of water push the root to grow more than that of high rate of water supply. 
Table 1. Chemical analysis of the irrigation water

\begin{tabular}{|c|c|c|c|c|c|c|c|c|c|c|}
\hline \multirow[t]{3}{*}{ pH } & \multicolumn{2}{|c|}{$\mathbf{E C}$} & \multicolumn{8}{|c|}{ Soluble ions (mq/l) } \\
\hline & \multirow[t]{2}{*}{ d.S/m } & \multirow[t]{2}{*}{ ppm } & \multicolumn{4}{|c|}{ Cations } & \multicolumn{4}{|c|}{ Anions } \\
\hline & & & $\mathrm{Ca}^{++}$ & $\mathrm{Mg}^{++}$ & $\mathrm{Na}^{+}$ & $\mathbf{K}^{+}$ & $\mathrm{Cl}^{-}$ & $\mathrm{HCo}_{3^{-}}$ & $\mathrm{Co}_{3^{--}}$ & $\mathrm{So}_{4^{--}}$ \\
\hline 6.6 & 5.49 & 35.14 & 17.22 & 19.17 & 19.29 & 0.31 & 37.51 & 5.21 & - & 13.27 \\
\hline
\end{tabular}

Table 2. Chemical and physical properties of the experimental soil during the two seasons

\begin{tabular}{|c|c|c|}
\hline Season & $2012 / 2013$ & $2013 / 2014$ \\
\hline \multicolumn{3}{|c|}{ Particle size distribution (\%) } \\
\hline Coarse sand (\%) & 68.30 & 68.28 \\
\hline Fine sand $(\%)$ & 20.54 & 20.66 \\
\hline Silt (\%) & 4.43 & 4.39 \\
\hline Clay (\%) & 6.72 & 6.67 \\
\hline Texture class & Sand & Sand \\
\hline Organic matter $(\%)$ & 0.19 & 0.21 \\
\hline \multicolumn{3}{|c|}{ Chemical analysis in extraction soil } \\
\hline \multicolumn{3}{|l|}{ a) Cations (mq/l) } \\
\hline $\mathrm{Ca}^{++}$ & 2.23 & 3.01 \\
\hline $\mathrm{Mg}^{++}$ & 2.25 & 2.22 \\
\hline $\mathrm{Na}^{+}$ & 3.99 & 3.82 \\
\hline $\mathrm{K}^{+}$ & 0.28 & 0.48 \\
\hline \multicolumn{3}{|l|}{ b) Anions (mq/l) } \\
\hline $\mathrm{HCo}^{-}$ & 2.38 & 2.35 \\
\hline $\mathrm{Cl}^{-}$ & 2.35 & 2.52 \\
\hline $\mathrm{So}_{4}^{--}$ & 4.02 & 4.67 \\
\hline $\mathrm{CaCo}_{3}(\%)$ & 4.77 & 4.78 \\
\hline $\mathrm{EC}(\mathrm{dS} / \mathrm{m})(1: 5)$ & 0.89 & 0.84 \\
\hline $\mathrm{pH}(1: 2.5)$ & 8.25 & 8.20 \\
\hline
\end{tabular}


In both seasons, the mean root length was different between the studied varieties at each level of irrigation $\times$ soil improver $(p<0.05)$. Marathon variety gave the highest values of root length (30.6 and $32.1 \mathrm{~cm}$ in $1^{\text {st }}$ and $2^{\text {nd }}$ seasons, respectively) followed by Farida variety that recorded $\left(29.0\right.$ and $30.5 \mathrm{~cm}$ in $1^{\text {st }}$ and $2^{\text {nd }}$ seasons, respectively). While Samba variety recorded the lowest values of root length in $1^{\text {st }}$ and $2^{\text {nd }}$ seasons, respectively $(27.3$ and $28.0 \mathrm{~cm})$. Where humic was applied at irrigation level of $3000 \mathrm{~m}^{3} / \mathrm{fad}$., the mean root lengths were statistically equivalent for the examined varieties of sugar beet $(\mathrm{F} 2,34=1.03, \mathrm{p}=0.3687)$. The differences between sugar beet varieties in root length had been reported by Ahmad et al. (2012) and Al-Sayed and Attaya (2015) who mentioned that sugar beet varieties were significantly differed in root length.

Therefore, all of the two-way interactions and all of the experimental factors were statistically significant as well. For each level of irrigation $\times$ variety the soil improver had a significant effect in $1^{\text {st }}$ season $(p<0.01)$. The highest root length was recorded by Iquet soil improver $\left(30.8\right.$ and $31.4 \mathrm{~cm}$ in $1^{\text {st }}$ and $2^{\text {nd }}$ seasons, respectively), followed by humic which gave $(29.2$ and $30.2 \mathrm{~cm})$. On the other hand, Agrispone attained the lowest values of root length during the two seasons. However, in $2^{\text {nd }}$ season, the mean root lengths for the Marathon variety were statistically equivalent for each experimental soil improver, at irrigation level 1 $\left(2500 \mathrm{~m}^{3} /\right.$ fad. $)(\mathrm{F} 2,34=1.14, \mathrm{p}=0.3315)$. In $2^{\text {nd }}$ season, the mean root lengths were statistically equivalent for the Samba variety across soil improvers at irrigation level of 3000 $\mathrm{m}^{3} /$ fad. $(\mathrm{F} 2,34=3.19, \mathrm{p}=0.0537)$.

The three-way interaction of irrigation $x$ variety $\times$ soil improver was statistically significant in $1^{\text {st }}$ season $(F 4,34=3.97, p=0,0095)$ (Table 3$)$, and also in $2^{\text {nd }}$ season $(\mathrm{F} 4,34=5.08, \mathrm{p}=0.0025)$ (Table 4). Using $2500 \mathrm{~m}^{3} / \mathrm{fad}$., of irrigation rate in combination with Iquet as soil improver for Marathon sugar beet variety were recorded the highest root length values in $1^{\text {st }}$ and $2^{\text {nd }}$ seasons $(35.2 \pm 0.4$ and $35.4 \pm 0.5 \mathrm{~cm}$, respectively). This finding is in agreement with that found by Al-Sayed and Osman (2015) who noted that highest root length was recorded with the combination between Marathon variety with $2500 \mathrm{~m}^{3} / \mathrm{fad}$., and Aquita component.

\section{Root Diameter}

Results in Tables 3 and 4 show that root diameter of sugar beet varieties significantly affected by the examined irrigation rates in both growing seasons also, in the $1^{\text {st }}$ season irrigation level had a significant effect on root diameter at each level of variety $\times$ soil improver, except when Farida variety was grown with Iquet (F1, $34=0.79, p=0.3806)$. In the $2^{\text {nd }}$ season, irrigation level had a significant effect on the root diameter at each level of variety $\times$ soil improver, except when Samba variety was grown with Humic $(\mathrm{F} 1,34=0.79, \mathrm{p}=0.3806)$. Moreover, results in Table 6 show that irrigation rate of $3000 \mathrm{~m}^{3} / \mathrm{fad}$ over passed that of 2500 $\mathrm{m}^{3} /$ fad which recorded the highest root diameter $\left(24.6 \mathrm{~cm}\right.$ in $1^{\text {st }}$ season and $25.7 \mathrm{~cm}$ in $2^{\text {nd }}$ season). This finding is in agreement with that found by Al-Sayed et al. (2014) who noted that root diameter was larger under the higher irrigation rate of $3000 \mathrm{~m}^{3}$.

Regarding the effect of sugar beet varieties on root diameter, results in Table 6 clear that Marathon variety gave the highest values of root diameter $\left(23.8\right.$ and $25.2 \mathrm{~cm}$ in $1^{\text {st }}$ and $2^{\text {nd }}$ seasons, respectively) followed by Farida variety that recorded $\left(23.7\right.$ and $25.0 \mathrm{~cm}$ in $1^{\text {st }}$ and $2^{\text {nd }}$ seasons, respectively). While Samba variety recorded the lowest values of root diameter in $1^{\text {st }}$ and $2^{\text {nd }}$ seasons, respectively $(22.2$ and $22.9 \mathrm{~cm})$. In both seasons, sugar beet varieties had a significant effect on root diameter when humic was applied at irrigation level of $2500 \mathrm{~m}^{3} /$ fad. $\left(1^{\text {st }}\right.$ season $\mathrm{F} 2,34=5.80, \mathrm{p}$ $=0.0068 ; 2^{\text {nd }}$ season F2, $\left.34=5.74, p=0.0071\right)$ and when Iquet was applied at irrigation rate of $2500 \mathrm{~m}^{3} /$ fad. $\left(1^{\text {st }}\right.$ season $\mathrm{F} 2,34=10.57, \mathrm{p}=$ $0.0003 ; 2^{\text {nd }}$ season F2, $\left.34=22.02, \mathrm{p}<0.0001\right)$. In both seasons, sugar beet varieties had a significant effect on root diameter at irrigation level of $3000 \mathrm{~m}^{3} / \mathrm{fad}$, when humic was applied $\left(1^{\text {st }}\right.$ season $\mathrm{F} 2,34=9.67, \mathrm{p}=0.0005 ; 2^{\text {nd }}$ season $\mathrm{F} 2,34=14.29, \mathrm{p}<0.0001)$. In $2^{\text {nd }}$ season, sugar beet varieties had a significant effect on root diameter when Agrispon was applied at irrigation level of $3000 \mathrm{~m}^{3} / \mathrm{fad}$., (F2,34 = 7.05, p $=0.0028$ ) and when Iquet was applied at irrigation level of $3000 \mathrm{~m}^{3} /$ fad., (F2,34 = 8.79, p $=0.0008)$. These findings are in agreement with those reported by Al-Sayed and Attaya (2015) who mentioned that sugar beet varieties were significantly differed in root diameter. 
Table 3. Least squares-means estimates \pm standard errors for first season, sugar beet variables with scheffé-adjusted grouping ${ }^{\dagger}$

\begin{tabular}{|c|c|c|c|c|c|}
\hline $\begin{array}{l}\text { Irrigation rate } \\
\left(\mathrm{m}^{3} / \text { fad. }\right)\end{array}$ & Variety & Soil improver & $\begin{array}{l}\text { Root length } \\
\text { (cm) }\end{array}$ & $\begin{array}{l}\text { Root diameter } \\
(\mathrm{cm})\end{array}$ & $\begin{array}{c}\text { Sucrose } \\
(\%)\end{array}$ \\
\hline \multirow{9}{*}{2500} & \multirow{3}{*}{ Farida } & Agrispon & $28.4 \pm 0.4^{\mathrm{def}}$ & $20.6 \pm 0.5^{\text {ef }}$ & $18.47 \pm 0.15^{\mathrm{abc}}$ \\
\hline & & Iquet & $33.3 \pm 0.4^{\mathrm{ab}}$ & $24.7 \pm 0.5^{\text {abcd }}$ & $19.40 \pm 0.15^{\mathrm{a}}$ \\
\hline & & Humic & $31.6 \pm 0.4^{\text {bcde }}$ & $22.3 \pm 0.5^{\text {abcdef }}$ & $19.23 \pm 0.15^{\mathrm{a}}$ \\
\hline & \multirow{3}{*}{ Samba } & Agrispon & $26.2 \pm 0.4^{\mathrm{fg}}$ & $20.9 \pm 0.5^{\mathrm{def}}$ & $17.67 \pm 0.15^{\mathrm{c}}$ \\
\hline & & Iquet & $32.2 \pm 0.4^{\mathrm{abcd}}$ & $21.4 \pm 0.5^{\text {cdef }}$ & $18.60 \pm 0.15^{\mathrm{abc}}$ \\
\hline & & Humic & $29.4 \pm 0.4^{\text {cdef }}$ & $20.3 \pm 0.5^{\mathrm{f}}$ & $18.47 \pm 0.15^{\mathrm{abc}}$ \\
\hline & \multirow{3}{*}{ Marathon } & Agrispon & $32.9 \pm 0.4^{\mathrm{abc}}$ & $21.9 \pm 0.5^{\text {bcdef }}$ & $18.50 \pm 0.15^{\mathrm{abc}}$ \\
\hline & & Iquet & $35.2 \pm 0.4^{\mathrm{a}}$ & $22.8 \pm 0.5^{\text {abcdef }}$ & $19.27 \pm 0.15^{\mathrm{a}}$ \\
\hline & & Humic & $33.5 \pm 0.4^{\mathrm{ab}}$ & $22.5 \pm 0.5^{\text {abcdef }}$ & $19.20 \pm 0.15^{\mathrm{ab}}$ \\
\hline \multirow{9}{*}{3000} & \multirow{3}{*}{ Farida } & Agrispon & $25.6 \pm 0.6^{\mathrm{fg}}$ & $24.3 \pm 0.5^{\text {abcdef }}$ & $18.77 \pm 0.15^{\mathrm{abc}}$ \\
\hline & & Iquet & $28.4 \pm 0.6^{\mathrm{def}}$ & $25.3 \pm 0.5^{\mathrm{abc}}$ & $19.53 \pm 0.15^{\mathrm{a}}$ \\
\hline & & Humic & $27.2 \pm 0.6^{\mathrm{fg}}$ & $25.6 \pm 0.5^{\mathrm{ab}}$ & $19.37 \pm 0.15^{\mathrm{a}}$ \\
\hline & \multirow{3}{*}{ Samba } & Agrispon & $23.7 \pm 0.6^{\mathrm{g}}$ & $23.2 \pm 0.5^{\mathrm{abcdef}}$ & $18.03 \pm 0.15^{\mathrm{bc}}$ \\
\hline & & Iquet & $26.5 \pm 0.6^{\mathrm{fg}}$ & $25.3 \pm 0.5^{\mathrm{abc}}$ & $19.20 \pm 0.15^{\mathrm{ab}}$ \\
\hline & & Humic & $26.3 \pm 0.6^{\mathrm{fg}}$ & $22.6 \pm 0.5^{\text {abcdef }}$ & $18.83 \pm 0.15^{\mathrm{abc}}$ \\
\hline & \multirow{3}{*}{ Marathon } & Agrispon & $25.4 \pm 0.6^{\mathrm{fg}}$ & $24.6 \pm 0.5^{\mathrm{abcde}}$ & $18.43 \pm 0.15^{\mathrm{abc}}$ \\
\hline & & Iquet & $29.8 \pm 0.6^{\text {bcdef }}$ & $26.3 \pm 0.5^{\mathrm{a}}$ & $19.40 \pm 0.15^{\mathrm{a}}$ \\
\hline & & Humic & $27.4 \pm 0.6^{\mathrm{efg}}$ & $24.7 \pm 0.5^{\mathrm{abcd}}$ & $19.57 \pm 0.15^{\mathrm{a}}$ \\
\hline
\end{tabular}

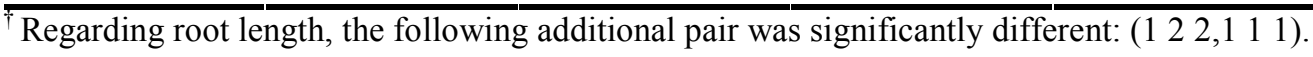

Table 4. Least squares-means estimates \pm standard errors for second season, sugar beet variables with scheffé-adjusted grouping ${ }^{\dagger}$

\begin{tabular}{|c|c|c|c|c|c|}
\hline $\begin{array}{l}\text { Irrigation rate } \\
\text { ( } \mathbf{m}^{3} / \text { fad.) }\end{array}$ & Variety & Soil improver & $\begin{array}{l}\text { Root length } \\
\text { (cm) }\end{array}$ & $\begin{array}{l}\text { Root diameter } \\
\text { (cm) }\end{array}$ & $\begin{array}{c}\text { Sucrose } \\
(\%)\end{array}$ \\
\hline \multirow{9}{*}{2500} & \multirow{3}{*}{ Farida } & Agrispon & $30.7 \pm 0.5^{\text {bcdef }}$ & $22.3 \pm 0.4^{\text {cde }}$ & $18.80 \pm 0.13^{\text {cde }}$ \\
\hline & & Iquet & $34.2 \pm 0.5^{\mathrm{ab}}$ & $24.9 \pm 0.4^{\mathrm{abcd}}$ & $20.37 \pm 0.15^{\mathrm{ab}}$ \\
\hline & & Humic & $33.4 \pm 0.5^{\mathrm{abc}}$ & $23.6 \pm 0.4^{\text {bcde }}$ & $19.53 \pm 0.16^{\mathrm{abcde}}$ \\
\hline & \multirow{3}{*}{ Samba } & Agrispon & $28.2 \pm 0.5^{\operatorname{defg}}$ & $21.0 \pm 0.4^{\mathrm{e}}$ & $18.30 \pm 0.16^{\mathrm{e}}$ \\
\hline & & Iquet & $31.8 \pm 0.5^{\mathrm{abcd}}$ & $21.7 \pm 0.4^{\mathrm{de}}$ & $18.53 \pm 0.12^{\text {de }}$ \\
\hline & & Humic & $30.7 \pm 0.5^{\text {bcdef }}$ & $22.3 \pm 0.4^{\text {cde }}$ & $18.77 \pm 0.14^{\text {cde }}$ \\
\hline & \multirow{3}{*}{ Marathon } & Agrispon & $35.2 \pm 0.5^{\mathrm{a}}$ & $22.2 \pm 0.4^{\text {cde }}$ & $19.00 \pm 0.15^{\text {cde }}$ \\
\hline & & Iquet & $35.4 \pm 0.5^{\mathrm{a}}$ & $25.6 \pm 0.4^{\mathrm{abc}}$ & $18.60 \pm 0.15^{\mathrm{de}}$ \\
\hline & & Humic & $34.3 \pm 0.5^{\mathrm{ab}}$ & $24.4 \pm 0.4^{\text {abcde }}$ & $19.27 \pm 0.12^{\text {bcde }}$ \\
\hline \multirow{9}{*}{3000} & \multirow{3}{*}{ Farida } & Agrispon & $27.2 \pm 0.5^{\mathrm{efg}}$ & $26.4 \pm 0.4^{\mathrm{ab}}$ & $19.00 \pm 0.13^{\text {cde }}$ \\
\hline & & Iquet & $29.2 \pm 0.5^{\text {cdefg }}$ & $26.7 \pm 0.4^{\mathrm{ab}}$ & $20.60 \pm 0.15^{\mathrm{a}}$ \\
\hline & & Humic & $28.7 \pm 0.5^{\operatorname{defg}}$ & $26.3 \pm 0.4^{\mathrm{ab}}$ & $20.50 \pm 0.16^{\mathrm{ab}}$ \\
\hline & \multirow{3}{*}{ Samba } & Agrispon & $25.4 \pm 0.5^{\mathrm{g}}$ & $24.4 \pm 0.4^{\text {abcde }}$ & $18.43 \pm 0.16^{\mathrm{de}}$ \\
\hline & & Iquet & $26.9 \pm 0.5^{\mathrm{fg}}$ & $24.9 \pm 0.4^{\mathrm{abcd}}$ & $19.73 \pm 0.12^{\mathrm{abc}}$ \\
\hline & & Humic & $25.2 \pm 0.5^{\mathrm{g}}$ & $23.3 \pm 0.4^{\text {bcde }}$ & $19.20 \pm 0.14^{\mathrm{cde}}$ \\
\hline & \multirow{3}{*}{ Marathon } & Agrispon & $27.6 \pm 0.5^{\operatorname{defg}}$ & $26.4 \pm 0.4^{\mathrm{ab}}$ & $19.23 \pm 0.15^{\text {bcde }}$ \\
\hline & & Iquet & $31.4 \pm 0.5^{\text {abcde }}$ & $27.4 \pm 0.4^{\mathrm{a}}$ & $19.63 \pm 0.15^{\mathrm{abcd}}$ \\
\hline & & Humic & $29.3 \pm 0.5^{\text {cdef }}$ & $25.9 \pm 0.4^{\mathrm{ab}}$ & $19.60 \pm 0.12^{\mathrm{abcd}}$ \\
\hline
\end{tabular}

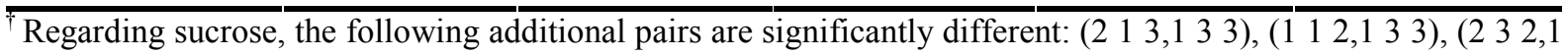
2 2), (2 33,122$)$, (2 33 3,2 2 1). 
Table 5. Effect of interaction between irrigation rates and soil improvers on root length of some sugar beet varieties

\begin{tabular}{|c|c|c|c|c|c|c|c|c|c|}
\hline \multirow{3}{*}{$\begin{array}{l}\text { Irrigation rate } \\
\mathrm{m}^{3} / \text { fad. }\end{array}$} & \multirow[t]{3}{*}{ Variety } & \multicolumn{4}{|c|}{$2012 / 2013$} & \multicolumn{4}{|c|}{$2013 / 2014$} \\
\hline & & \multicolumn{3}{|c|}{ Soil improver } & \multirow{2}{*}{ Mean } & \multicolumn{3}{|c|}{ Soil improver } & \multirow[t]{2}{*}{ Mean } \\
\hline & & Agrispon & Iquet & $\overline{\text { Humic }}$ & & Agrispon & Iquet & Humic & \\
\hline & Farida & 28.4 & 33.3 & 31.6 & 31.1 & 30.7 & 34.2 & 33.4 & 32.7 \\
\hline \multirow[t]{2}{*}{2500} & Samba & 26.2 & 32.2 & 29.4 & 29.2 & 28.2 & 31.8 & 30.7 & 30.2 \\
\hline & Marathon & 32.9 & 35.2 & 33.5 & 33.8 & 35.2 & 35.4 & 34.3 & 34.9 \\
\hline \multirow[t]{2}{*}{ Mean } & & 29.1 & 33.5 & 31.5 & 31.3 & 31.3 & 33.8 & 32.8 & 32.6 \\
\hline & Farida & 25.6 & 28.4 & 27.2 & 27.0 & 27.2 & 29.2 & 28.7 & 28.3 \\
\hline \multirow[t]{2}{*}{3000} & Samba & 23.7 & 26.5 & 26.3 & 25.5 & 25.4 & 26.9 & 25.2 & 25.8 \\
\hline & Marathon & 25.4 & 29.8 & 27.4 & 27.5 & 27.6 & 31.4 & 29.3 & 29.4 \\
\hline Mean & & 24.9 & 28.2 & 26.9 & 26.6 & 26.7 & 29.1 & 27.7 & 27.8 \\
\hline \multicolumn{2}{|c|}{ Soil improvers mean } & 27.0 & 30.8 & 29.2 & & 29.0 & 31.4 & 30.2 & \\
\hline & Farida & & & & 29.0 & & & & 30.5 \\
\hline \multirow[t]{2}{*}{ Varieties mean } & Samba & & & & 27.3 & & & & 28.0 \\
\hline & Marathon & & & & 30.6 & & & & 32.1 \\
\hline
\end{tabular}

Table 6. Effect of interaction between irrigation rates and soil improvers on root diameter of some sugar beet varieties

\begin{tabular}{|c|c|c|c|c|c|c|c|c|c|}
\hline \multirow{3}{*}{$\begin{array}{l}\text { Irrigation rate } \\
\mathrm{m}^{3} / \text { fad. }\end{array}$} & \multirow[t]{3}{*}{ Variety } & \multicolumn{4}{|c|}{$2012 / 2013$} & \multicolumn{4}{|c|}{$2013 / 2014$} \\
\hline & & \multicolumn{3}{|c|}{$\begin{array}{c}\text { Soil improver } \\
\end{array}$} & \multirow[t]{2}{*}{ Mean } & \multicolumn{3}{|c|}{ Soil improver } & \multirow{2}{*}{ Mean } \\
\hline & & $\overline{\text { Agrispon }}$ & Iquet & Humic & & Agrispon & Iquet & Humic & \\
\hline & Farida & 20.6 & 24.7 & 22.3 & 22.5 & 22.3 & 24.9 & 23.6 & 23.6 \\
\hline \multirow[t]{2}{*}{2500} & Samba & 20.9 & 21.4 & 20.3 & 20.8 & 21.0 & 21.7 & 22.3 & 21.6 \\
\hline & Marathon & 21.9 & 22.8 & 22.5 & 22.4 & 22.2 & 25.6 & 24.4 & 24.0 \\
\hline \multirow[t]{2}{*}{ Mean } & & 21.1 & 22.9 & 21.7 & 21.9 & 21.8 & 24.0 & 23.4 & 23.0 \\
\hline & Farida & 24.3 & 25.3 & 25.6 & 25.0 & 26.4 & 26.7 & 26.3 & 26.4 \\
\hline \multirow[t]{2}{*}{3000} & Samba & 23.2 & 25.3 & 22.6 & 23.7 & 24.4 & 24.9 & 23.3 & 24.2 \\
\hline & Marathon & 24.6 & 26.3 & 24.7 & 25.2 & 26.4 & 27.4 & 25.9 & 26.5 \\
\hline Mean & & 24.0 & 25.6 & 24.3 & 24.6 & 25.7 & 26.3 & 25.1 & 25.7 \\
\hline \multicolumn{2}{|c|}{ Soil improvers mean } & 22.5 & 24.2 & 23.0 & & 23.7 & 25.1 & 24.2 & \\
\hline & Farida & & & & 23.7 & & & & 25.0 \\
\hline \multirow[t]{2}{*}{ Varieties mean } & Samba & & & & 22.2 & & & & 22.9 \\
\hline & Marathon & & & & 23.8 & & & & 25.2 \\
\hline
\end{tabular}


Concerning the effect of soil improvers on root diameter, results in Table 6 show that the highest root diameter was recorded due to Iquet soil improver application $(24.2$ and $25.1 \mathrm{~cm}$ in $1^{\text {st }}$ and $2^{\text {nd }}$ seasons, respectively), followed by Humic which gave $(23.0$ and $24.2 \mathrm{~cm})$. On the other hand, the lowest values of root diameter during the two seasons were attained due to Agrispone application. This finding is in line with those reported by Al-Sayed and Attaya (2015) who mentioned that Aquita compound recorded the highest values of root diameter. Moreover, In both seasons, the soil improver had a statistically significant effect on Farida root diameter at irrigation level of $2500 \mathrm{~m}^{3} / \mathrm{fad}$., $\left(1^{\text {st }}\right.$ season F2,34 $=16.64, \mathrm{p}<0.0001 ; 2^{\text {nd }}$ season $\mathrm{F} 2,34=8.93, \mathrm{p}=0.0008)$ and on Samba root diameter at irrigation level of $3000 \mathrm{~m}^{3} / \mathrm{fad}$., $\left(1^{\text {st }}\right.$ season $F 2,34=7.78, p=0.0016 ; 2^{\text {nd }}$ season $\mathrm{F} 2,34=3.67, \mathrm{p}=0.0362)$. In $1^{\text {st }}$ season, the soil improver had a significant effect on Marathon root diameter at irrigation $3000 \mathrm{~m}^{3} / \mathrm{fad}$., (F2, 34 $=3.57, \mathrm{p}=0.0391)$. In $2^{\text {nd }}$ season, the soil conditioner had a significant effect on Marathon variety root diameter at irrigation $2500 \mathrm{~m}^{3} / \mathrm{fad}$., $(\mathrm{F} 2,34=15.38, \mathrm{p}<0.0001)$.

The three-way interaction of irrigation $x$ variety $\times$ soil improver was significant in $1^{\text {st }}$ season $(\mathrm{F} 4,34=3.87, \mathrm{p}=0.0107)$ (Table 3$)$ but not in $2^{\text {nd }}$ season $(\mathrm{F} 4,34=1.87, \mathrm{p}=0.1380)$ (Table 4). Moreover, using $3000 \mathrm{~m}^{3} / \mathrm{fad}$, of irrigation rate in combination with Iquet as soil improver for Marathon sugar beet variety recorded the highest root diameter values in $1^{\text {st }}$ and $2^{\text {nd }}$ seasons $(26.3 \pm 0.5$ and $27.4 \pm 0.4 \mathrm{~cm}$, respectively).

\section{Sucrose Percentage}

Sucrose percentage is one of the important parameters that briefly give an idea about the expected sugar extractives. Results given in Tables 3 and 4 show that sucrose percentage of sugar beet varieties significantly affected by the examined irrigation rates in both growing seasons. In both seasons, irrigation levels had a significant effect on sucrose when Samba variety was grown with Iquet $\left(1^{\text {st }}\right.$ season $\mathrm{F} 1,34$ $=8.63, \mathrm{p}=0.0059 ; 2^{\text {nd }}$ season $\mathrm{F} 1,34=49.85, \mathrm{p}$ $<0.0001)$. In $2^{\text {nd }}$ season, however, the irrigation levels also had a significant effect when Farida variety was grown with Humic $(\mathrm{F} 1,34=18.28$, $\mathrm{p}=0.0001)$, when Samba variety was grown with Humic $(\mathrm{F} 1,34=4.97, \mathrm{p}=0.0325)$, and when Marathon variety was grown with Iquet $(\mathrm{F} 1,34=24.03, \mathrm{p}<0.0001)$. Moreover, results in Table 7 show that irrigation rate of 3000 $\mathrm{m}^{3} /$ fad., over passed that of $2500 \mathrm{~m}^{3} / \mathrm{fad}$., which recorded the highest percentage of sucrose $\left(19.01 \%\right.$ in $1^{\text {st }}$ season and $19.54 \%$ in $2^{\text {nd }}$ season). This result is in line with that reported by ElHennawy and El-Hawary (1995) who found that increasing depletion level of soil moisture significantly increased sucrose percentage.

Regarding the effect of sugar beet varieties on sucrose percentage, results in Table 7 clear that Farida variety gave the highest values of this trait in $1^{\text {st }}$ and $2^{\text {nd }}$ seasons (19.12 and $19.79 \%$ ), respectively followed by Marathon variety that recorded (19.06 and $19.21 \%$ in $1^{\text {st }}$ and $2^{\text {nd }}$ seasons, respectively). While Samba variety recorded the lowest values of sucrose percentage in $1^{\text {st }}$ and $2^{\text {nd }}$ seasons, respectively (18.46 and $18.82 \%)$. Therefore, varieties had significant effect for most of the levels of irrigation $\times$ soil improver in $1^{\text {st }}$ season $(p<$ 0.005 ), except when Iquet was applied at irrigation rate of $3000 \mathrm{~m}^{3} / \mathrm{fad}$., (F2, $34=1.35$, p $=0.2727)$. In $2^{\text {nd }}$ season, varieties had a significant effect for every level of irrigation $\times$ soil improver $(\mathrm{p} \leq 0.01)$.

Once more, the effect of soil improvers on sucrose percentage, results in Table 7 show that the highest percentage was recorded by Iquet soil improver (19.23 and $19.57 \%$ in $1^{\text {st }}$ and $2^{\text {nd }}$ seasons, respectively), followed by Humic which gave (19.10 and $19.47 \%)$. On the other hand, Agrispone produced the lowest values of sucrose percentage during the two seasons. However in $1^{\text {st }}$ season, for every level of irrigation $\times$ variety, the soil improver had a significant effect $(\mathrm{p}<0.005)$, but in $2^{\text {nd }}$ season, the soil improver did not have a significant effect on Samba variety sucrose levels at irrigation rate of $2500 \mathrm{~m}^{3} / \mathrm{fad}$. (F2, $34=2.47$, p $=0.0993)$, and the soil improver did not have a significant effect on Marathon variety sucrose levels at irrigation rate of $3000 \mathrm{~m}^{3} / \mathrm{fad}$., (F2,34 = $2.24, \mathrm{p}=0.1224$ ).

The three-way interaction of irrigation $x$ variety $\times$ soil improver did not have a significant effect on sucrose percentage in $1^{\text {st }}$ season $(\mathrm{F} 4,34$ 
Table 7. Effect of interactions between irrigation rates and soil improvers on sucrose percentage of some sugar beet varieties

\begin{tabular}{|c|c|c|c|c|c|c|c|c|c|}
\hline \multirow{3}{*}{$\begin{array}{l}\text { Irrigation rate } \\
\mathrm{m}^{3} / \text { fad. }\end{array}$} & \multirow[t]{3}{*}{ Variety } & \multicolumn{4}{|c|}{$2012 / 2013$} & \multicolumn{4}{|c|}{$2013 / 2014$} \\
\hline & & \multicolumn{3}{|c|}{ Soil improver } & \multirow[t]{2}{*}{ Mean } & \multicolumn{3}{|c|}{ Soil improver } & \multirow[t]{2}{*}{ Mean } \\
\hline & & Agrispon & Iquet & Humic & & Agrispon & Iquet & Humic & \\
\hline & Farida & 18.47 & 19.40 & 19.23 & 19.03 & 18.80 & 20.37 & 19.53 & 19.56 \\
\hline \multirow[t]{2}{*}{2500} & Samba & 17.67 & 18.60 & 18.47 & 18.24 & 18.30 & 18.53 & 18.77 & 18.53 \\
\hline & Marathon & 18.50 & 19.27 & 19.20 & 18.99 & 19.00 & 18.60 & 19.27 & 18.95 \\
\hline \multirow[t]{2}{*}{ Mean } & & 18.21 & 19.09 & 18.96 & 18.75 & 18.70 & 19.16 & 19.19 & 19.01 \\
\hline & Farida & 18.77 & 19.53 & 19.37 & 19.22 & 19.00 & 20.60 & 20.50 & 20.03 \\
\hline \multirow[t]{2}{*}{3000} & Samba & 18.03 & 19.20 & 18.83 & 18.68 & 18.43 & 19.73 & 19.20 & 19.12 \\
\hline & Marathon & 18.43 & 19.40 & 19.57 & 19.13 & 19.23 & 19.63 & 19.60 & 19.48 \\
\hline Mean & & 18.41 & 19.37 & 19.25 & 19.01 & 18.88 & 19.98 & 19.76 & 19.54 \\
\hline \multicolumn{2}{|c|}{ Soil improvers mean } & 18.31 & 19.23 & 19.10 & & 18.79 & 19.57 & 19.47 & \\
\hline & Farida & & & & 19.12 & & & & 19.79 \\
\hline \multirow[t]{2}{*}{ Varieties mean } & Samba & & & & 18.46 & & & & 18.82 \\
\hline & Marathon & & & & 19.06 & & & & 19.21 \\
\hline
\end{tabular}

$=0.80, \mathrm{p}=0.5349)($ Table 3$)$. Nevertheless, in $2^{\text {nd }}$ season, the three-way interaction had a significant effect on sucrose percentage $(\mathrm{F} 4,34=$ 4.42, $\mathrm{p}=0.0055$ ) (Table 4). The Scheffé adjustment that was used in the Tables is a single-step adjustment for multiple comparisons, so it was not necessary for the $\mathrm{F}$ ratio for the three-way interaction to be statistically significant in order for the differences between the levels of the three-way interaction to be considered to be statistically significant. Furthermore, using $3000 \mathrm{~m}^{3} /$ fad., of irrigation rate in combination with Iquet as soil improver for Farida sugar beet variety recorded the highest sucrose percentage value $(20.06 \%$ as a mean of both seasons) followed by the same variety with the same irrigation rate but with Humic as soil improver that gave $(19.93 \%$ as a mean of both seasons).

\section{Juice Purity Percentage}

Results given in Tables 8 and 9 point out that purity percentage of sugar beet varieties significantly affected by the examined irrigation rates in $1^{\text {st }}$ season, the irrigation levels had a significant effect on purity only when Farida variety was grown with Agrispon (F1,34 = 24.24, $\mathrm{p}<0.0001)$ and when Marathon variety was grown with Iquet $(\mathrm{F} 1,34=13.35, \mathrm{p}=$ 0.0009 ). Irrigation rate of $2500 \mathrm{~m}^{3} / \mathrm{fad}$., over passed that of $3000 \mathrm{~m}^{3} / \mathrm{fad}$., only in the $1^{\text {st }}$ season (Table 10) which recorded the highest purity percentage $(94.24 \%)$, this finding is in agreement with that found by Al-Sayed et al. (2014) who noted that irrigation rate of $2500 \mathrm{~m}^{3}$ recorded significantly higher purity (\%) than $3000 \mathrm{~m}^{3}$. Nevertheless, in the $2^{\text {nd }}$ season, the rate of $3000 \mathrm{~m}^{3} / \mathrm{fad}$., over passed that of $2500 \mathrm{~m}^{3} /$ fad., that attained $95.19 \%$. As for the combination of both seasons, the irrigation rate of $3000 \mathrm{~m}^{3} / \mathrm{fad}$., over passed the other rate on purity percentage trait.

As for the effect of sugar beet varieties on purity percentage, results in Table 10 clear that Farida variety gave the highest value of this trait in each of $1^{\text {st }}$ and $2^{\text {nd }}$ seasons (95.07 and $95.80 \%$ ), respectively followed by Marathon variety that recorded $\left(94.25\right.$ and $95.42 \%$ in $1^{\text {st }}$ and $2^{\text {nd }}$ seasons, respectively). While Samba variety recorded the lowest values of this trait in both seasons. Furthermore, in $1^{\text {st }}$ season, the variety 
Table 8. Least squares-means estimates \pm standard errors for $1^{\text {st }}$ season, sugar beet variables with scheffé-adjusted grouping ${ }^{\dagger}$

\begin{tabular}{|c|c|c|c|c|c|}
\hline $\begin{array}{l}\text { Irrigation rate } \\
\text { ( } \mathrm{m}^{3} / \text { fad.) }\end{array}$ & Variety & Soil improver & Purity (\%) & $\begin{array}{l}\text { Root yield } \\
\text { (ton/fad.) }\end{array}$ & $\begin{array}{c}\text { Sugar yield } \\
\text { (ton/fad.) }\end{array}$ \\
\hline \multirow{9}{*}{2500} & \multirow{3}{*}{ Farida } & Agrispon & $94.00 \pm 0.34^{\text {abcd }}$ & $23.24 \pm 0.24^{\mathrm{ef}}$ & $4.29 \pm 0.06^{\mathrm{hi}}$ \\
\hline & & Iquet & $96.11 \pm 0.28^{\mathrm{ab}}$ & $27.60 \pm 0.24^{\mathrm{bc}}$ & $5.35 \pm 0.06^{\mathrm{abc}}$ \\
\hline & & Humic & $94.33 \pm 0.33^{\mathrm{abcd}}$ & $26.29 \pm 0.24^{\mathrm{cd}}$ & $5.06 \pm 0.06^{\mathrm{cde}}$ \\
\hline & \multirow{4}{*}{ Samba } & Agrispon & $93.33 \pm 0.36^{\mathrm{cd}}$ & $21.95 \pm 0.24^{\mathrm{fg}}$ & $3.88 \pm 0.06^{\mathrm{ij}}$ \\
\hline & & Iquet & $94.22 \pm 0.34^{\mathrm{abcd}}$ & $25.45 \pm 0.24^{\mathrm{d}}$ & $4.73 \pm 0.06^{\mathrm{efg}}$ \\
\hline & & Humic & $92.66 \pm 0.37^{\mathrm{d}}$ & $23.51 \pm 0.24^{\mathrm{ef}}$ & $4.34 \pm 0.06^{\mathrm{gh}}$ \\
\hline & & Agrispon & $93.66 \pm 0.35^{\mathrm{bcd}}$ & $24.46 \pm 0.24^{\mathrm{de}}$ & $4.52 \pm 0.06^{\mathrm{ggh}}$ \\
\hline & \multirow[t]{3}{*}{ Marathon } & Iquet & $96.22 \pm 0.27^{\mathrm{ab}}$ & $28.09 \pm 0.24^{\mathrm{abc}}$ & $5.41 \pm 0.06^{\mathrm{abc}}$ \\
\hline & & Humic & $93.66 \pm 0.35^{\mathrm{bcd}}$ & $25.47 \pm 0.24^{\mathrm{d}}$ & $4.89 \pm 0.06^{\mathrm{def}}$ \\
\hline \multirow{9}{*}{3000} & & Agrispon & $94.11 \pm 0.34^{\text {abcd }}$ & $23.12 \pm 0.22^{\mathrm{efg}}$ & $4.34 \pm 0.06^{\mathrm{gh}}$ \\
\hline & \multirow[t]{3}{*}{ Farida } & Iquet & $95.44 \pm 0.30^{\mathrm{abc}}$ & $28.70 \pm 0.22^{\mathrm{ab}}$ & $5.61 \pm 0.06^{\mathrm{ab}}$ \\
\hline & & Humic & $96.44 \pm 0.27^{\mathrm{a}}$ & $27.27 \pm 0.22^{b c}$ & $5.28 \pm 0.06^{\mathrm{bcd}}$ \\
\hline & & Agrispon & $92.44 \pm 0.38^{\mathrm{d}}$ & $21.42 \pm 0.22^{\mathrm{g}}$ & $3.86 \pm 0.06^{\mathrm{j}}$ \\
\hline & \multirow[t]{3}{*}{ Samba } & Iquet & $93.77 \pm 0.35^{\mathrm{bcd}}$ & $28.22 \pm 0.22^{\mathrm{ab}}$ & $5.42 \pm 0.06^{\mathrm{abc}}$ \\
\hline & & Humic & $93.33 \pm 0.36^{\mathrm{cd}}$ & $25.52 \pm 0.22^{\mathrm{d}}$ & $4.81 \pm 0.06^{\mathrm{ef}}$ \\
\hline & & Agrispon & $93.33 \pm 0.36^{\mathrm{cd}}$ & $24.64 \pm 0.22^{\mathrm{de}}$ & $4.54 \pm 0.06^{\mathrm{fgh}}$ \\
\hline & \multirow[t]{2}{*}{ Marathon } & Iquet & $94.66 \pm 0.32^{\mathrm{abcd}}$ & $29.42 \pm 0.22^{\mathrm{a}}$ & $5.71 \pm 0.06^{\mathrm{a}}$ \\
\hline & & Humic & $94.00 \pm 0.34^{\text {abcd }}$ & $29.43 \pm 0.22^{\mathrm{a}}$ & $5.76 \pm 0.06^{\mathrm{a}}$ \\
\hline
\end{tabular}

Table 9. Least squares-means estimates \pm standard errors for $2^{\text {nd }}$ season, sugar beet variables with scheffé-adjusted grouping ${ }^{\dagger}$

\begin{tabular}{|c|c|c|c|c|c|}
\hline $\begin{array}{l}\text { Irrigation rate } \\
\text { ( } \mathbf{m}^{3} / \text { fad.) }\end{array}$ & Variety & Soil improver & $\begin{array}{c}\text { Purity } \\
(\%)\end{array}$ & $\begin{array}{l}\text { Root yield } \\
\text { (ton/fad.) }\end{array}$ & $\begin{array}{c}\text { Sugar yield } \\
\text { (ton/fad.) }\end{array}$ \\
\hline \multirow{9}{*}{2500} & \multirow{3}{*}{ Farida } & Agrispon & $94.44 \pm 0.42^{\mathrm{ab}}$ & $24.54 \pm 0.19^{i}$ & $4.61 \pm 0.05^{\mathrm{h}}$ \\
\hline & & Iquet & $96.66 \pm 0.29^{\mathrm{a}}$ & $28.42 \pm 0.19^{\mathrm{def}}$ & $5.79 \pm 0.05^{\mathrm{abc}}$ \\
\hline & & Humic & $95.33 \pm 0.39^{\mathrm{ab}}$ & $27.59 \pm 0.19^{\text {fg }}$ & $5.39 \pm 0.05^{\text {cde }}$ \\
\hline & \multirow{4}{*}{ Samba } & Agrispon & $93.22 \pm 0.46^{\mathrm{b}}$ & $22.16 \pm 0.19^{j}$ & $4.05 \pm 0.05^{\mathrm{i}}$ \\
\hline & & Iquet & $95.00 \pm 0.36^{\mathrm{ab}}$ & $27.11 \pm 0.19^{\mathrm{fg}}$ & $5.02 \pm 0.05^{\mathrm{efg}}$ \\
\hline & & Humic & $94.66 \pm 0.41^{\mathrm{ab}}$ & $26.16 \pm 0.19^{\text {gh }}$ & $4.91 \pm 0.05^{\mathrm{fgh}}$ \\
\hline & & Agrispon & $94.55 \pm 0.41^{\mathrm{ab}}$ & $25.25 \pm 0.19^{\mathrm{hi}}$ & $4.80 \pm 0.05^{\mathrm{gh}}$ \\
\hline & \multirow[t]{3}{*}{ Marathon } & Iquet & $95.44 \pm 0.34^{\mathrm{ab}}$ & $29.44 \pm 0.19^{\mathrm{bcd}}$ & $5.48 \pm 0.05^{\mathrm{bcd}}$ \\
\hline & & Humic & $96.11 \pm 0.35^{\mathrm{ab}}$ & $27.60 \pm 0.19^{\mathrm{fg}}$ & $5.32 \pm 0.05^{\mathrm{def}}$ \\
\hline \multirow{9}{*}{3000} & & Agrispon & $94.33 \pm 0.42^{\mathrm{ab}}$ & $25.60 \pm 0.19^{\mathrm{hi}}$ & $4.86 \pm 0.07^{\mathrm{fgh}}$ \\
\hline & \multirow[t]{3}{*}{ Farida } & Iquet & $97.00 \pm 0.28^{\mathrm{a}}$ & $30.55 \pm 0.19^{\mathrm{ab}}$ & $6.29 \pm 0.07^{\mathrm{a}}$ \\
\hline & & Humic & $97.11 \pm 0.31^{\mathrm{a}}$ & $29.51 \pm 0.19^{\mathrm{bcd}}$ & $6.05 \pm 0.07^{\mathrm{a}}$ \\
\hline & & Agrispon & $94.22 \pm 0.42^{\mathrm{ab}}$ & $22.21 \pm 0.19^{j}$ & $4.09 \pm 0.07^{\mathrm{i}}$ \\
\hline & \multirow[t]{3}{*}{ Samba } & Iquet & $94.55 \pm 0.37^{\mathrm{ab}}$ & $29.07 \pm 0.19^{\text {cde }}$ & $5.74 \pm 0.07^{\mathrm{abcd}}$ \\
\hline & & Humic & $93.11 \pm 0.46^{\mathrm{b}}$ & $27.76 \pm 0.19^{\mathrm{ef}}$ & $5.33 \pm 0.07^{\text {cdef }}$ \\
\hline & & Agrispon & $94.44 \pm 0.42^{\mathrm{ab}}$ & $25.59 \pm 0.19^{\mathrm{hi}}$ & $4.92 \pm 0.07^{\mathrm{efgh}}$ \\
\hline & \multirow[t]{2}{*}{ Marathon } & Iquet & $95.89 \pm 0.32^{\mathrm{ab}}$ & $30.34 \pm 0.19^{\mathrm{abc}}$ & $5.96 \pm 0.07^{\mathrm{ab}}$ \\
\hline & & Humic & $96.11 \pm 0.35^{\mathrm{ab}}$ & $31.74 \pm 0.19^{\mathrm{a}}$ & $6.22 \pm 0.07^{\mathrm{a}}$ \\
\hline
\end{tabular}

Regarding sugar yield, the following additional pairs are significantly different: $\left(\begin{array}{llllll}2 & 1 & 2,1 & 1 & 2\end{array}\right),\left(\begin{array}{llllll}1 & 1 & 2,1 & 1 & 3\end{array}\right),\left(\begin{array}{ll}1 & 3\end{array}\right.$ $3,123)$. 
had a significant effect on purity for most levels of irrigation $\times$ soil improver $(\mathrm{p}<0.01)$, except when Agrispon was applied at irrigation level of $2500 \mathrm{~m}^{3} /$ fad., $\left(1^{\text {st }}\right.$ season $\mathrm{F} 2,34=0.91, \mathrm{p}=$ $0.4122 ; 2^{\text {nd }}$ season $\mathrm{F} 2,34=3.00, \mathrm{p}=0.0630$ ). In $2^{\text {nd }}$ season, the variety also did not have a significant effect when Agrispon was applied at $3000 \mathrm{~m}^{3} /$ fad., irrigation level (F2, $34=0.07, \mathrm{p}=$ 0.9293).

Concerning the effect of soil improvers on purity percentage, results in Table 10 show that the highest percentage was recorded by Iquet soil improver ( 95.06 and $95.75 \%$ in $1^{\text {st }}$ and $2^{\text {nd }}$ seasons, respectively), followed by Humic which gave (94.07 and 95.40\%). On the other hand, Agrispone produced the lowest values of this trait during the two seasons. However, in $1^{\text {st }}$ season, the soil improver had a significant effect on purity at every level of the irrigation $x$ variety interaction $(p<0.05)$. In $2^{\text {nd }}$ season, the soil improver had a significant effect on purity at most levels of the irrigation $\times$ variety interaction $(\mathrm{p}<0.05)$, except when Samba variety was grown at $3000 \mathrm{~m}^{3} / \mathrm{fad}$., irrigation level $(\mathrm{F} 2,34=3.26, \mathrm{p}=0.0507)$.

The three-way interaction of irrigation $x$ variety $\times$ soil improver did not have a significant effect on purity in $1^{\text {st }}$ season $(\mathrm{F} 4,34=2.53, \mathrm{p}=$ 0.0588 ) (Table 8 ). Nevertheless, in $2^{\text {nd }}$ season, the three-way interaction had a significant effect on purity (F4, $34=4.51, \mathrm{p}=0.0050)$ (Table 9). Moreover, using $3000 \mathrm{~m}^{3} / \mathrm{fad}$., of irrigation rate in combination with Humic as soil improver for Farida sugar beet variety recorded the highest purity percentage values in $1^{\text {st }}$ and $2^{\text {nd }}$ seasons ( 96.44 and $97.11 \%$, respectively).

\section{Root Yield (ton/fad.)}

Results given in Tables 8 and 9 show that root yield of sugar beet varieties significantly affected by the examined irrigation rates in both growing seasons. In the $1^{\text {st }}$ season, irrigation treatments had a significant effect on root yield at most levels of variety $\times$ soil improver $(\mathrm{p}<$ 0.005 ) except when Farida variety was grown with Agrispon $(\mathrm{F} 1,34=0.15, \mathrm{p}=0.7031)$, Samba variety was grown with Agrispon (F1,34 $=2.85, \mathrm{p}=0.1007)$, and when Marathon variety was grown with Agrispon (F1, $34=0.33, \mathrm{p}=$ 0.5680 ). Similarly, in the $2^{\text {nd }}$ season, irrigation treatments had a significant effect on root yield at most levels of variety $\times$ soil improver $(\mathrm{p}<$ 0.005 ), except when Samba variety was grown with Agrispon (F1, $34=0.04, p=0.8467)$ and when Marathon variety was grown with Agrispon $(\mathrm{F} 1,34=1.76, \mathrm{p}=0.1940)$. However, results in Table (11) show that irrigation rate of $3000 \mathrm{~m}^{3} / \mathrm{fad}$., over passed that of $2500 \mathrm{~m}^{3} / \mathrm{fad}$., which recorded the highest root yields (26.41 and 28.03 ton/fad., in $1^{\text {st }}$ and $2^{\text {nd }}$ seasons, respectively). The results are in harmony with that found by Abd El-Wahab et al. (1996) and El-Hawary et al. (2013) who reported that root yield (ton/fad.) was significantly increased as the level of irrigation increased.

Regarding the effect of sugar beet varieties on root yield, results in Table 11 clear that Marathon variety gave the highest values of root yield (26.91 and 28.32 ton/fad., in $1^{\text {st }}$ and $2^{\text {nd }}$ seasons, respectively) followed by Farida variety that recorded (26.03 and 27.70 ton/fad., in $1^{\text {st }}$ and $2^{\text {nd }}$ seasons, respectively). While Samba variety recorded the lowest values of root yield in both seasons. Varieties had a significant effect on root yield at every level of irrigation $\times$ soil improver in $1^{\text {st }}$ season $(\mathrm{p}<0.005)$ and $2^{\text {nd }}$ season $(\mathrm{p}<0.0001)$. The results are in line with that reported by Al-Sayed and Osman (2015). The differences between varieties in this character could be due to the differences between the used varieties in their genetically aspects.

Concerning the effect of soil improvers on root yield, results in Table 11 show that the highest root yield was recorded by Iquet soil improver (27.91 and 29.15 ton/fad., in $1^{\text {st }}$ and $2^{\text {nd }}$ seasons, respectively), followed by Humic which gave (26.24 and 28.39 ton/fad). On the other hand, Agrispone gave the lowest values of root yield during the two seasons. In both seasons, soil improver had a highly significant effect on root yield at every level of irrigation $x$ variety $(p<0.0001)$. The influence of soil conditioners on root yield had been reported by Zarishnyak and Sypko (2010) and Ambihai and Gnanavelrajah (2013) who mentioned that the addition of press mud and charred biomass had the potential to increase the root yield by improving soil properties.

The three-way interaction of irrigation $x$ variety $\times$ soil improver had a significant effect on sugar beet root yield in $1^{\text {st }}$ season $(F 4,34=$ 
Table 10. Effect of interactions between irrigation rates and soil improvers on purity percentage of some sugar beet varieties

\begin{tabular}{|c|c|c|c|c|c|c|c|c|c|}
\hline \multirow{3}{*}{$\begin{array}{l}\text { Irrigation rate } \\
\mathrm{m}^{3} / \text { fad. }\end{array}$} & \multirow[t]{3}{*}{ Variety } & \multicolumn{4}{|c|}{$2012 / 2013$} & \multicolumn{4}{|c|}{$2013 / 2014$} \\
\hline & & \multicolumn{3}{|c|}{ Soil improver } & \multirow[t]{2}{*}{ Mean } & \multicolumn{3}{|c|}{ Soil improver } & \multirow{2}{*}{ Mean } \\
\hline & & Agrispon & Iquet & Humic & & Agrispon & Iquet & Humic & \\
\hline & Farida & 94.00 & 96.11 & 94.33 & 94.81 & 94.44 & 96.66 & 95.33 & 95.47 \\
\hline \multirow[t]{2}{*}{2500} & Samba & 93.33 & 94.22 & 92.66 & 93.40 & 93.22 & 95.00 & 94.66 & 94.29 \\
\hline & Marathon & 93.66 & 96.22 & 93.66 & 94.51 & 94.55 & 95.44 & 96.11 & 95.36 \\
\hline \multirow[t]{2}{*}{ Mean } & & 93.66 & 95.51 & 93.55 & 94.24 & 94.07 & 95.70 & 95.36 & 95.04 \\
\hline & Farida & 94.11 & 95.44 & 96.44 & 95.33 & 94.33 & 97.00 & 97.11 & 96.14 \\
\hline \multirow[t]{2}{*}{3000} & Samba & 92.44 & 93.77 & 93.33 & 93.18 & 94.22 & 94.55 & 93.11 & 93.96 \\
\hline & Marathon & 93.33 & 94.66 & 94.00 & 93.99 & 94.44 & 95.89 & 96.11 & 95.48 \\
\hline Mean & & 93.29 & 94.62 & 94.59 & 94.16 & 94.33 & 95.81 & 95.44 & 95.19 \\
\hline \multicolumn{2}{|c|}{ Soil improvers mean } & 93.47 & 95.06 & 94.07 & & 94.20 & 95.75 & 95.40 & \\
\hline & Farida & & & & 95.07 & & & & 95.80 \\
\hline \multirow[t]{2}{*}{ Varieties mean } & Samba & & & & 93.29 & & & & 94.12 \\
\hline & Marathon & & & & 94.25 & & & & 95.42 \\
\hline
\end{tabular}

Table 11. Effect of interactions between irrigation rates and soil improvers on root yield of some sugar beet varieties

\begin{tabular}{|c|c|c|c|c|c|c|c|c|c|}
\hline \multirow{3}{*}{$\begin{array}{l}\text { Irrigation rate } \\
\mathrm{m}^{3} / \text { fad. }\end{array}$} & \multirow[t]{3}{*}{ Variety } & \multicolumn{4}{|c|}{$2012 / 2013$} & \multicolumn{4}{|c|}{$2013 / 2014$} \\
\hline & & \multicolumn{3}{|c|}{ Soil improver } & \multirow[t]{2}{*}{ Mean } & \multicolumn{3}{|c|}{ Soil improver } & \multirow{2}{*}{ Mean } \\
\hline & & Agrispon & Iquet & Humic & & Agrispon & Iquet & Humic & \\
\hline & Farida & 23.24 & 27.60 & 26.29 & 25.71 & 24.54 & 28.42 & 27.59 & 26.85 \\
\hline \multirow[t]{2}{*}{2500} & Samba & 21.95 & 25.45 & 23.51 & 23.63 & 22.16 & 27.11 & 26.16 & 25.14 \\
\hline & Marathon & 24.46 & 28.09 & 25.47 & 26.00 & 25.25 & 29.44 & 27.60 & 27.43 \\
\hline \multirow[t]{2}{*}{ Mean } & & 23.21 & 27.04 & 25.09 & 25.11 & 23.98 & 28.32 & 27.11 & 26.47 \\
\hline & Farida & 23.12 & 28.70 & 27.27 & 26.36 & 25.60 & 30.55 & 29.51 & 28.55 \\
\hline \multirow[t]{2}{*}{3000} & Samba & 21.42 & 28.22 & 25.52 & 25.05 & 22.21 & 29.07 & 27.76 & 26.34 \\
\hline & Marathon & 24.64 & 29.42 & 29.43 & 27.83 & 25.59 & 30.34 & 31.74 & 29.22 \\
\hline Mean & & 23.06 & 28.78 & 27.40 & 26.41 & 24.46 & 29.98 & 29.67 & 28.03 \\
\hline \multicolumn{2}{|c|}{ Soil improvers mean } & 23.13 & 27.91 & 26.24 & & 24.22 & 29.15 & 28.39 & \\
\hline & Farida & & & & 26.03 & & & & 27.70 \\
\hline \multirow[t]{2}{*}{ Varieties mean } & Samba & & & & 24.34 & & & & 25.74 \\
\hline & Marathon & & & & 26.91 & & & & 28.32 \\
\hline
\end{tabular}


$11.15, \mathrm{p}<0.0001)($ Table 8$)$ and in $2^{\text {nd }}$ season $(\mathrm{F} 4,34=17.70, \mathrm{p}<0.0001)$ (Table 9). Moreover, using $3000 \mathrm{~m}^{3} /$ fad., of irrigation rate in combination with Humic as soil improver for Marathon sugar beet variety were recorded the highest root yield values in $1^{\text {st }}$ and $2^{\text {nd }}$ seasons ( $29.43 \pm 0.2$ and $31.74 \pm 0.1 \mathrm{ton} / \mathrm{fad}$, respectively).

\section{Sugar Yield (ton/fad.)}

Results given in Tables 8 and 9 show that in the $1^{\text {st }}$ season, the irrigation treatments had a significant effect for most levels of variety $\times$ soil improver $(\mathrm{p}<0.005)$, except when Farida variety was grown with Agrispon $(\mathrm{F} 1,34=0.42$, $\mathrm{p}=0.5194)$ - and, in both seasons, irrigation treatments did not have a significant effect when Samba variety was grown with Agrispon $\left(1^{\text {st }}\right.$ season F1, $34=0.05, \mathrm{p}=0.8271 ; 2^{\text {nd }}$ season $\mathrm{F} 1,34=0.21, \mathrm{p}=0.6506)$ and when Marathon variety was grown with Agrispon $\left(1^{\text {st }}\right.$ season $\mathrm{F} 1,34=0.06, \mathrm{p}=0.8060 ; 2^{\text {nd }}$ season $\mathrm{F} 1,34=$ $2.11, \mathrm{p}=0.1556)$. Therefore, results in Table 12 show that irrigation rate of $3000 \mathrm{~m}^{3} /$ fad., over passed that of $2500 \mathrm{~m}^{3} / \mathrm{fad}$., which recorded the highest sugar yields (5.03 and 5.49 ton/fad., in $1^{\text {st }}$ and $2^{\text {nd }}$ seasons, respectively). This finding is in harmony with that found by Abd El-Wahab et al. (1996) and El-Hawary et al. (2013) who mentioned that increasing quantity or the level of irrigation water increased significantly sugar yield (ton/fad.).

Varieties had a significant effect on sugar yield at every level of irrigation $\times$ soil improver in both seasons $(p<0.005)$. Results in Table 12 clear that Marathon variety gave the highest values of sugar yield (5.13 ton/fad, in $1^{\text {st }}$ season) however, in the $2^{\text {nd }}$ season, Farida variety recorded the highest sugar yield (5.49 ton/fad). While Samba variety recorded the lowest values of sugar yield in both seasons. These findings are in agreement with those reported by ElHennawy and El-Hawary (1995), Al-Sayed (1997), El-Hawary and Mokadem (1999), AbouSalama and El-Sayed (2000), Nassar (2001), ElHinnawy et al. (2003), El-Hawary et al. (2013) and Al-Sayed and Attaya (2015) who mentioned that sugar beet varieties were significantly differed in sugar yield.

Table 12. Effect of interactions between irrigation rates and soil improvers on sugar yield of some sugar beet varieties

\begin{tabular}{|c|c|c|c|c|c|c|c|c|c|}
\hline \multirow{3}{*}{$\begin{array}{l}\text { Irrigation rate } \\
\mathbf{m}^{3} / \text { fad. }\end{array}$} & \multirow[t]{3}{*}{ Variety } & \multicolumn{4}{|c|}{$2012 / 2013$} & \multicolumn{4}{|c|}{$2013 / 2014$} \\
\hline & & \multicolumn{3}{|c|}{ Soil improver } & \multirow[t]{2}{*}{ Mean } & \multicolumn{3}{|c|}{ Soil improver } & \multirow[t]{2}{*}{ Mean } \\
\hline & & $\overline{\text { Agrispon }}$ & Iquet & Humic & & $\overline{\text { Agrispon }}$ & Iquet & Humic & \\
\hline & Farida & 4.29 & 5.35 & 5.06 & 4.90 & 4.61 & 5.79 & 5.39 & 5.26 \\
\hline \multirow[t]{2}{*}{2500} & Samba & 3.88 & 4.73 & 4.34 & 4.31 & 4.05 & 5.02 & 4.91 & 4.66 \\
\hline & Marathon & 4.52 & 5.41 & 4.89 & 4.94 & 4.80 & 5.48 & 5.32 & 5.20 \\
\hline \multirow[t]{2}{*}{ Mean } & & 4.23 & 5.16 & 4.76 & 4.71 & 4.48 & 5.43 & 5.20 & 5.04 \\
\hline & Farida & 4.34 & 5.61 & 5.28 & 5.07 & 4.86 & 6.29 & 6.05 & 5.73 \\
\hline \multirow[t]{2}{*}{3000} & Samba & 3.86 & 5.42 & 4.81 & 4.69 & 4.09 & 5.74 & 5.33 & 5.05 \\
\hline & Marathon & 4.54 & 5.71 & 5.76 & 5.33 & 4.92 & 5.96 & 6.22 & 5.70 \\
\hline Mean & & 4.24 & 5.58 & 5.28 & 5.03 & 4.62 & 5.99 & 5.86 & 5.49 \\
\hline \multicolumn{2}{|c|}{ Soil improvers mean } & 4.23 & 5.37 & 5.02 & & 4.55 & 5.71 & 5.53 & \\
\hline \multirow{3}{*}{ Varieties mean } & Farida & & & & 4.98 & & & & 5.49 \\
\hline & Samba & & & & 4.50 & & & & 4.85 \\
\hline & Marathon & & & & 5.13 & & & & 5.45 \\
\hline
\end{tabular}


Concerning the effect of soil improvers on sugar yield, results in Table 12 show that the highest sugar yield was recorded by Iquet soil improver $\left(5.37\right.$ and $5.71 \mathrm{ton} / \mathrm{fad}$, in $1^{\text {st }}$ and $2^{\text {nd }}$ seasons, respectively), followed by Humic which gave (5.02 and 5.53 ton/fad). On the other hand, Agrispone produced the lowest values of sugar yield during the two seasons. In both seasons, soil improver had a highly significant effect on sugar yield at every level of irrigation $\times$ variety $(p<0.0001)$. The influence of soil conditioners on sugar yield had been reported by Blomquist and Berglund (2002), Wallace and Carter (2007) and Zarishnyak and Sypko (2010) who mentioned that the addition of soil conditioner improved the experimental soil and increased sugar yield.

The three-way interaction of irrigation $x$ variety $\times$ soil improver had a significant effect on sugar yield in the $1^{\text {st }}$ season $(\mathrm{F} 4,34=11.26, \mathrm{p}$ $<0.0001)$ (Table 8) and in $2^{\text {nd }}$ season (F4,34 = $5.09, \mathrm{p}=0.0025$ ) (Table 9). Moreover, using $3000 \mathrm{~m}^{3} / \mathrm{fad}$., of irrigation rate in combination with Humic as soil improver for Marathon sugar beet variety recorded the highest sugar yield values in $1^{\text {st }}$ and $2^{\text {nd }}$ seasons (5.76 and 6.22 ton/fad., respectively).

\section{Conclusion}

It can be concluded that the studied varieties especially Marathon and/or Farida irrigated with $3000 \mathrm{~m}^{3} / \mathrm{fad}$., with using Iquet as soil improver could be recommended for maximizing sugar beet productivity and juice quality under the environmental conditions of El-Arish, North Sinai, Egypt.

\section{Acknowledgments}

Deep gratitude to Sugar Crops Research Institute, Agricultural Research Centre, Giza, Egypt specially Prof. Dr. Hussein Al-Sayed, professor of agronomy for using Sugar beet seed material and invaluable help. Also, special thanks and deep appreciation are to Prof. Dr. Ibrahim Hanafy El-Geddawy, professor of Agronomy for encouragement and kind advices.

\section{REFERENCES}

Abd El-Wahab, S., A.A. Amer, M.L. ElShahawy and M.M. Sabh (1996). Effect of different irrigation amounts and potassium fertilizer rates on yield and quality of sugar beet and water efficiencies. J. Agric. Sci., Mansoura Univ., 21 (2): 4687-4699.

Abou-Salama, A.M. and S.I. El-Sayed (2000). Studies on some sugar beet cultivars under Middle Egypt condition. I-Response to planting and harvesting dates. Assiut J., Agric. Sci., 31 (1): 137-159.

Ahmad, S., M. Zubair, N. Iqbal, N.M. Cheema and K. Mahmood (2012). Evaluation of sugar beet hybrid varieties under ThalKumbi soil series of Pakistan. Int. J. Agric. and Biol., 14 (4): 605-608.

Al-Sayed, H.M. (1997). Studies on yield and yield component of some sugar beet varieties. M.Sc. Thesis, Fac. Agric., Al-Azhar Univ., Egypt.

Al-Sayed, H.M. and A.M. Osman (2015). Yield and quality of two sugar beet varieties as affected by water regimes and soil treatments. Zagazig J. Agric. Res., 42 (5): 927 - 938.

Al-Sayed, H.M. and A.S. Attaya (2015). Effect of seed treatment and weed control methods on yield and quality of some sugar beet varieties. Zagazig J. Agric. Res., 42 (5): 939951.

Al-Sayed, H.M., A.Sh.A. Osman and Sh.B.I. ElAdway (2014). Effects of irrigation water quality and application rates of sprinkler irrigation on yield and quality of some sugar beet varieties. Egypt. J. Appl. Sci., 29 (5): 158-177.

Ambihai, S. and N. Gnanavelrajah (2013). Improving soil productivity through charred biomass amendment to soil. Ame-Eurasian J. Agric. and Environ. Sci., 13 (10): 1345-1350.

AOAC (1990). Official Methods of Analysis. Association of Official Agricultural Chemists, $15^{\text {th }}$ Ed. Washington, DC, USA.

Bhullar, M.S., S.K. Uppal and M.L. Kapur (2009). Effect of agronomic practices and varieties on productivity of sugar beet (Beta vulgaris L.) in semi-arid region of Punjab. J. Res., Punjab Agric. Univ., 46 (1/2): 6-8.

Blomquist, J. and K. Berglund (2002). Affirmed with slaked lime. Increased yields and invigorated soils. Betodlaren., (3): 50-53. 
Carruthers, A. and J.F.T. Old Field (1961). Methods for the assessment of sugar beet quality. Int. Sug., 63 (1):103-105.

Duncan, D.B. (1995). Multiple Range and Multiple F tests. Biometrics, 11, 1-42.

El-Hawary, M.A., E.M. Soliman, I.M. AbdelAziz, M. El-Shereif and S.A. Mohamed (2013). Effect of irrigation water quantity, sources and rates of nitrogen on growth, yield and quality of sugar beet. Res. J. Agric. and Biol. Sci., 9 (1): 58-69.

El-Hawary, M.A and S.A Mokadem (1999). Tolerance of some sugar beet varieties to irrigations with saline water in sandy soils. Assiut J. Agric. Sci., 30 (1):1-11.

El-Hennawy, M.A. and M.A. El-Hawary (1995). Response of some sugar beet varieties to different soil moisture levels. Egypt. J. Appl. Sci., 10 (12): 139-147.

El-Hinnawy, H.H., E. Ahmed, B.S.H. Ramadan, M.A Farag, E.M. Al-Jbawi, M.R. Mahmoud, P. Baron and M.R. Bayoumi (2003). Variety $\mathrm{x}$ environment interaction in sugar beet yield trails. Proc. Int. Conf. on Arab Region and Africa in the world Sugar Context. Aswan, Egypt 9-12 March.

FAS USDA (2016). Sugar: World Markets and Trade. Foreign Agricultural Service/ United States Department of Agriculture. Office of Global Analysis. https://apps.fas.usda. gov/ psdonline/ circulars/Sugar.pdf.

Ijoyah, M.O., V.L. Sophie and H. Rakotomavo (2008). Yield performance of four beet root (Beta vulgaris L.) varieties compared with the local variety under open field conditions in Seychelles. Agro-Sci., 7 (2): 139-142.

LiangMin, W., G. Ming, J. QingDe, S. GuiRong, L. ChunXin and G. AnJiang (2014). Adaptability analysis of new sugar beet varieties in Xinjiang of China. Sugar Crops of China, (2):30-32.

Nassar, A.M. (2001). Effect of plant density on the productivity of some sugar beet varieties. J. Agric. Sci., Mansoura Univ., 26 (12): 7533-7546.
Negm, M.A., A.A. Mohammedein, R.N. Zaki and A.I.A. Elmeneasy (2005). Response of sugar beet and corn crops to sawdust compost and farmyard manure with combination of $\mathrm{N}$ sources: 1 . in relation to the effective properties of a calcareous soil. Egyptian J. Soil Sci., 45(3):279-296.

Pacuta, V., I. Cerny and J. Pulkrabek (2013). Influence of variety and foliar preparations containing bioactive substances on root yield, sugar content and polarized sugar yield of sugar beet. Listy Cukrovarnicke a Reparske, 129 (11): 337-340.

Ramazan, T., S.H. Sinan and A. Bilal (2011). Effect of different drip irrigation regimes on sugar beet (Beta vulgaris L.) yield, quality and water use efficiency in Middle Anatolian, Turkey. Irrig. Sci., 29: 79-89.

Safina, S.A. and E.M. Fatah (2011). Response of three sugar beet varieties to compost, mineral nitrogen fertilizer and their combination under sandy soil conditions: II- Yield and quality. Bull. Fac. Agric., Cairo Univ., 62 (4): 447-456

Siodmiak, J. (2007) Post-registration assessment of sugar beet varieties in 2006. Gazeta Cukrownicza, 115 (2): 65-68.

Soomro, A.F., A. Ahmed, S. Junejo and M.A. Rajput (2006). Root yield and quality performance of different sugar beet varieties under different sowing dates at NSCRI, Thatta. Indus. J. Plant Sci., 5 (1): 665- 669.

Steel, R.G.D., J.H. Torrie and D.A. Dicky (1997). Principles and Procedures of Statistics, a Biological Approach. $3^{\text {rd }}$ Ed. MacGraw Hill Book Co. New Yourk, 172 177.

Wallace, P. and C. Carter (2007). Effects of compost on yields of winter wheat and barley, sugar beet, onion and swede in the fourth and fifth years of a rotation. HGCA Project Report, $422: 31$.

Zarishnyak, A.S. and A.A. Sypko (2010). Chemical improvement of soil and sugar beet productivity. Sakharnaya Svekla., (1):21-24. 
قسم الإنتاج النباتي ـ كلية العلوم الزر اعية البيئية ـ جامعة العريش ـ شمال سيناء ـ مصر

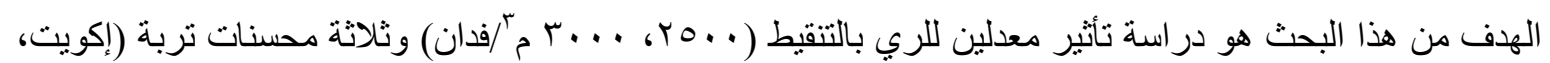

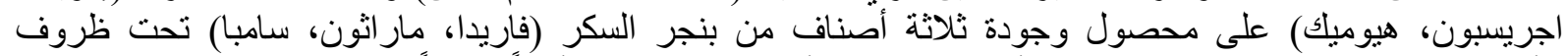

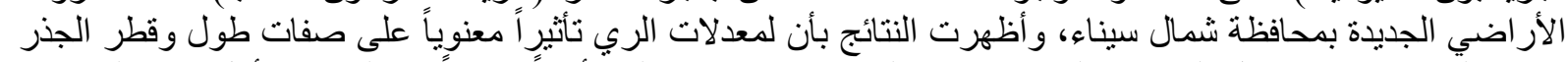

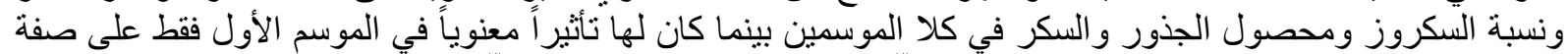

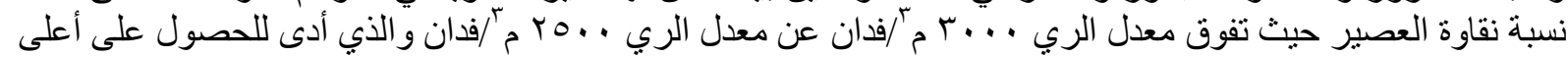

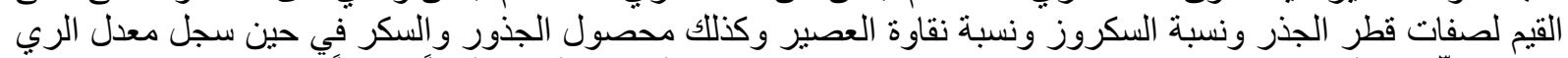

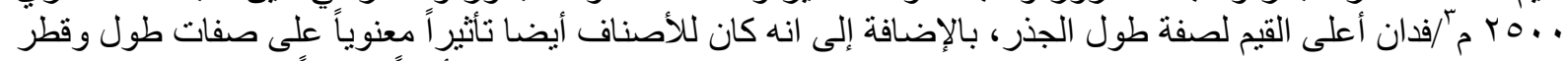

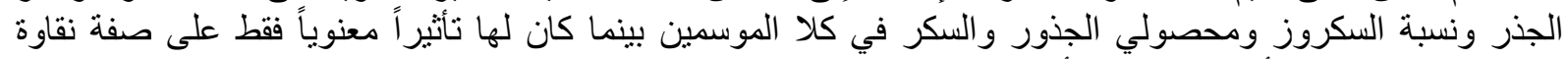

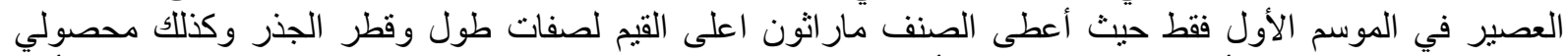

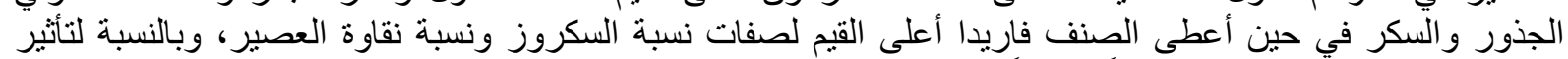

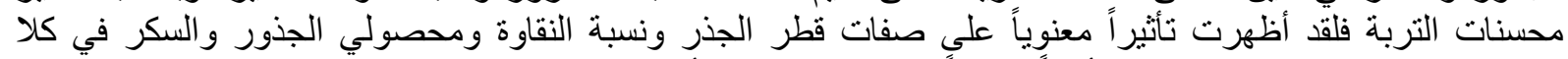

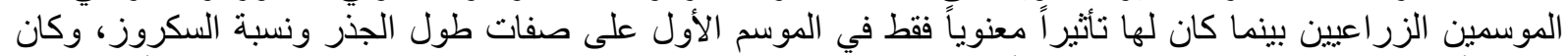

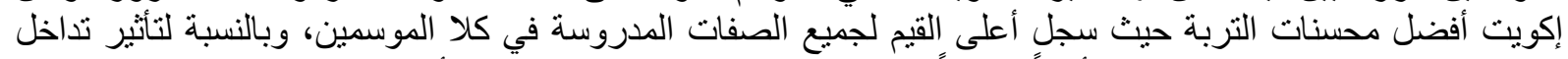

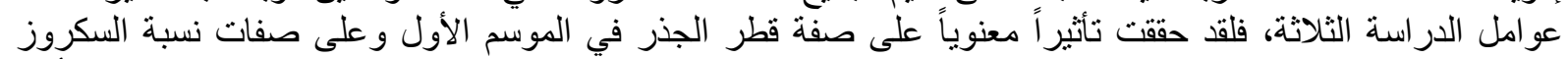

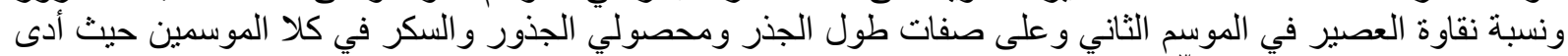

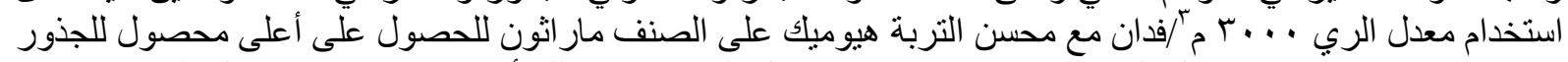

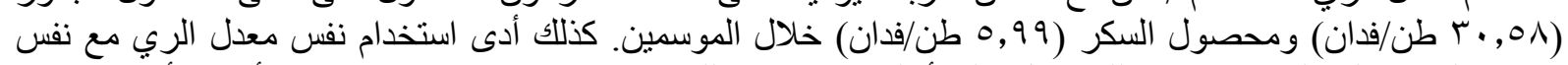

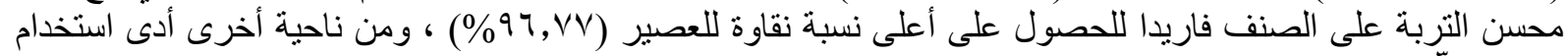

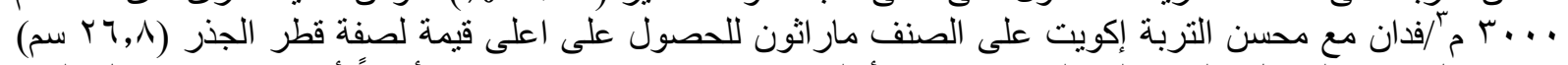

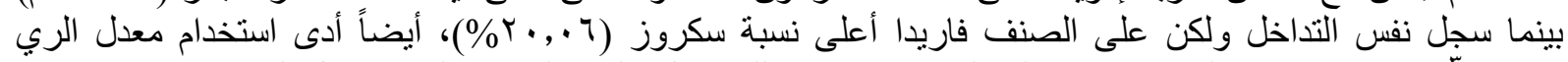

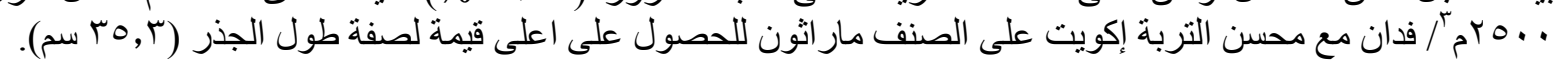

